\title{
Sistem Pendukung Keputusan Pemilihan Madrasah Ibtidaiyah Terbaik Dengan Kombinasi Metode Profile Matching Dan Fuzzy SAW
}

\author{
Decision Support System for the Best Madrasah Ibtidaiyah Selection with a Combination of Profile \\ Matching Methods and Fuzzy SAW \\ Indah Widiastuti ${ }^{1}$, Lili Tanti ${ }^{2}$, Daifiria ${ }^{2}$ \\ ${ }^{1,2,3}$ Program Studi Sistem Informasi, Fakultas Teknik dan Ilmu Komputer \\ Universitas Potensi Utama, Jl.K.L. Yos Sudarso KM 6.5 Tanjung Mulia-Medan \\ E-mail: Indahwidiastuti9811@gmail.com ${ }^{1}$,lilitanti82@gmail.com²,upu.daifiria@gmail.com ${ }^{3}$
}

\begin{abstract}
ABSTRAK
Saat ini Kantor Kementrian Agama Kab. Langkat belum menggunakan sistem dalam pengambilan keputusan yang berkaitan dengan Pemilihan Madrasah Ibtidaiyah Terbaik, sebelumnya masyarakat hanya bertanya kepada tetangga untuk mengetahui apakah madrasah tersebut terbaik atau tidak. Masalah yang terjadi masyarakat tidak adanya data yang efesien untuk membuktikan madrasah tersebut terbaik atau tidak. Untuk itu memerlukan suatu sistem yang dapat membantu Kantor Kementrian Agama dalam pengambilan keputusan Pemilihan madrasah ibtidaiyah terbaik dengan menyediakan alternative pilihan dengan mempertimbangkan beberapa unsur dari setiap kriteria yang sudah ditentukan. Adapun hasil penelitian: Aplikasi sistem pendukung keputusan yang di bangun dapat memberikan keputusan dalam pemilihan madrasah ibtidaiyah terbaik.
\end{abstract}

Kata Kunci: Pemilihan Madrasah Ibtidaiyah, Sistem Pendukung Keputusan, Kombinasi Metode Profile Matching dan Fuzzy SAW

\section{ABSTRACT}

Currently the Office of the Ministry of Religion Kab. Langkat has not used the system in decisionmaking related to the selection of the Best Madrasah Ibtidaiyah, previously the community only asked neighbors to see whether the madrasah was the best or not. The problem that occurs in the community is that there is no efficient data to prove whether the madrasah is the best or not. For that we need a system that can assist the Office of the Ministry of Religion in making decisions on choosing the best madrasah ibtidaiyah by providing alternative options by considering several elements of each determined criteria. The results of the study: The application of the decision support system that was built can provide decisions in the selection of the best madrasah ibtidaiyah.

Keywords: Selection of Madrasah Ibtidaiyah Decision Support Systems, Combinations of Profile Matching Methods and Fuzzy SAW

\section{PENDAHULUAN}

Madrasah Ibtidaiyah merupakan lembaga pendidikan Islam yang menjadi madrasah atau sekolah terbanyak yang berada dibawah Kementerian Agama yang sebagian besar berstatus swasta dan berada di pedesaan.[1] Banyak terdapat Madrasah Ibtidaiyah disetiap kota, sehingga para orang tua juga ingin memilih madrasah yang terbaik untuk anaknya, dengan harapan anak-anaknya mendapatkan ilmu pengetahuan yang bermanfaat dan menjadikan anaknya cerdas intelektual dan spiritual. Biasanya untuk memilih madrasah yang terbaik para orang tua bertanya kepada beberapa orang yang anakanaknya bersekolah di madrasah. Masalah yang terjadi adalah tidak adanya jaminan yang pasti bahwasannya madrasah yang dituju adalah yang terbaik dari madrasah lainnya karena setiap penilaian beberapa orang memiliki hasil yang berbeda. 
Oleh karena itu peneliti memanfaatkan teknologi komputer untuk membantu para orang tua yang ingin mendapatkan keputusan untuk anaknya menuntut ilmu di madrasah dengan menerapkan sistem komputer. Sistem yang dapat digunakan adalah sistem pendukung keputusan. Sistem pendukung keputusan adalah bagian dari sistem informasi berbasis komputer yang dipakai untuk mendukung pengambilan keputusan dalam suatu organisasi atau perusahaan.[2] Namun untuk dapat menggunakan sistem pendukung keputusan maka dibutuhkan metode yang tepat untuk mengelola data-data kriteria keputusan sehingga mendapatkan keputusan yang sesuai. Oleh karena itu peneliti merekomendasikan metode profile matching. Metode profile matching adalah metode yang sering dipakai sebagai mekanisme dalam pengambilan keputusan dengan mengasumsikan bahwa terdapat tingkat variabel prediktor yang ideal yang harus dipenuhi oleh subyek yang diteliti. [3]. Namun peneliti tertarik untuk mengkombinasikan dua metode sistem pendukung keputusan sehingga mendapatkan keputusan yang lebih baik. Peneliti menggabungkan metode Profile Matching dengan metode fuzzy SAW. Fuzzy SAW merupakan penggabungan dari metode SAW dengan logika matematika Fuzzy.[4]. Dengan adanya penerapan sistem pendukung keputusan menggunakan kombinasi metode profile matching dan fuzzy SAW maka dapat menghasilkan keputusan yang lebih tepat dan lebih baik.

\section{METODE PENELITIAN}

Metode merupakan suatu cara yang sistematik untuk mengerjakan suatu permasalahan. Penelitian ini akan melalui beberapa tahapan. Tahapan dalam penelitian ini dapat di modelkan pada diagram alur. Adapun beberapa tahapan yang digunakan dalam penelitian ini adalah sebagai berikut :

Pengumpulan data menggunakan beberapa tahapan yang peneliti lakukan untuk mendapatkan datadata yang dibutuhkan yaitu :

1. Lapangan

Pengumpulan data dilapangan memiliki dua tahapan yang harus dilakukan yaitu :

a. Observasi

Peneliti melakukan observasi ke Kantor Kementrian Agama untuk melakukan riset penelitian dan mendapatkan data-data yang dibutuhkan.

b. Wawancara

Peneliti melakukan tanya jawab kepada Bapak Andri Syafrizal pada bagian pengurusan izin madrasah untuk mendapatkan keterangan lebih lanjut untuk penelitian ini.

c. Sample

Peneliti mengambil beberapa sample yang berkaitan dengan penelitian diantaranya data-data madrasah.

2. Kepustakaan

Peneliti menggunakan buku, jurnal dan karya ilmiah sebagai referensi dan landasan teori pada penelitian ini.

Penelitian ini akan melalui beberapa tahapan. Tahapan dalam penelitian ini dapat di modelkan pada diagram alur sebagai berikut :

Mulai

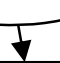

Analisa Kebutuhan

Identifikasi Masalah 
Keterangan :

Gambar 1. Diagram Alur Metode Penelitian

1. Analisa Kebutuhan

Pada tahapan ini peneliti mengumpulkan data-data yang berkaitan dengan penelitian dari Dinas Kementrian agama. Peneliti juga menentukan software dan hardware yang akan digunakan untuk membuat penelitian.

Berikut adalah data-data yang dibutuhkan mendapatkan hasil keputusan Madrasah Ibtidaiyah terbaik :

a. Data Madrasah

b. Data Hasil Wawancara

Berikut adalah bahan bacaan yang digunakan untuk teori :

a. Buku

b. Jurnal

2. Identifikasi Masalah

Masalah yang teridentifikasi adalah bahwa sulitnya melakukan pemilihan Madrasah Ibtidaiyah terbaik.

3. Pengumpulan Data

Peneliti melakukan pengumpulan data ke Dinas kementerian agama untuk mendapatkan data-data yang berkaitan dengan pemillihan Madrasah Ibtidaiyah.

4. Desain Sistem

Untuk mendesain sistem peneliti menggunakan beberapa pemodelan UML yaitu :

a. Use case diagram

Dengan menggunakan use case diagram maka peneliti dapat menggambarkan cara kerja aktor yang berkaitan dengan sistem sehingga dapat membentuk class dan attribute.

b. Class diagram 
Dengan menggunakan class diagram maka peneliti dapat membuat struktur basis data yang akan digunakan.

c. Activity diagram

Dengan menggunakan activity diagram maka peneliti dapat menggambarkan aktifitas dari aktor pada sistem.

d. Sequence diagram.

Dengan sequence diagram maka peneliti dapat menggambarkan urutan penggunaan sistem untuk mengelola data.

5. Penulisan Kode Program

Dalam penulisan kode program, peneliti menggunakan bahasa pemrograman PHP dengan menggunakan basis data MySQL sebagai penyimpanan data.

6. Pengujian Program

Pengujian program dilakukan untuk mengetahui kekurangan sistem. Apabila terdapat kekurangan sistem atau program tidak berjalan dengan baik, maka akan dilakukan perbaikan sampai seluruh program berjalan dengan baik. Pengujian dengan teori menggunakan blackbox tesing dan pengujian dengan praktek menggunakan $\mathrm{Web}$.

7. Hasil

Pada tahapan ini penelitian ini sudah menghasilkan aplikasi Sistem Pendukung Keputusan Pemilihan Madrasah Ibtidaiyah Terbaik Dengan Kombinasi Metode Profile Matching Dan Fuzzy SAW.

\section{HASIL DAN PEMBAHASAN}

Banyak terdapat Madrasah Ibtidaiyah disetiap kota, sehingga para orang tua juga ingin memilih madrasah yang terbaik untuk anaknya, dengan harapan anak-anaknya mendapatkan ilmu pengetahuan yang bermanfaat dan menjadikan anaknya cerdas intelektual dan spiritual. Biasanya untuk memilih madrasah yang terbaik para orang tua bertanya kepada beberapa orang yang anak-anaknya bersekolah di madrasah. Masalah yang terjadi adalah tidak adanya jaminan yang pasti bahwasannya madrasah yang dituju adalah yang terbaik dari madrasah lainnya karena setiap penilaian beberapa orang memiliki hasil yang berbeda. Oleh karena itu peneliti memanfaatkan teknologi komputer untuk membantu para orang tua yang ingin mendapatkan keputusan untuk anaknya menuntut ilmu di madrasah dengan menerapkan sistem komputer. Sistem yang dapat digunakan adalah sistem pendukung keputusan. Namun untuk dapat menggunakan sistem pendukung keputusan maka dibutuhkan metode yang tepat untuk mengelola data-data kriteria keputusan sehingga mendapatkan keputusan yang sesuai. Oleh karena itu peneliti merekomendasikan metode profile matching. Namun peneliti tertarik untuk mengkombinasikan dua metode sistem pendukung keputusan sehingga mendapatkan keputusan yang lebih baik. Peneliti menggabungkan metode Profile Matching dengan metode fuzzy SAW. Dengan adanya penerapan sistem pendukung keputusan menggunakan kombinasi metode profile matching dan fuzzy SAW maka dapat menghasilkan keputusan yang lebih tepat dan lebih baik.

Studi Kasus :

1. Penentuan kriteria

Untuk kriteria dari sistem pendukung keputusan pemilihan madrasah ibtidaiyah terbaik dapat ditunjukkan pada tabel dibawah ini :

Tabel 1 Tabel Kriteria

\begin{tabular}{|c|c|}
\hline Kriteria & Keterangan \\
\hline$(\mathrm{C} 1)$ & Akreditasi \\
\hline$(\mathrm{C} 2)$ & Biaya \\
\hline$(\mathrm{C} 3)$ & Lokasi \\
\hline$(\mathrm{C} 4)$ & Jumlah Pelajar \\
\hline
\end{tabular}

Untuk pembobotan setiap kriteria menggunakan cara pemberian nilai pada masing-masing kriteria secara langsung. Dengan perhitungan sederhana, yaitu : 
Total Bobot $=100 \%$.

2. Pembobotan Kriteria

Pembobotan kriteria dapat dilihat pada tabel dibawah ini :

Tabel 2 Tabel Pembobotan Kriteria

\begin{tabular}{|c|c|c|c|}
\hline \multicolumn{4}{|c|}{ Kriteria } \\
\hline Akreditasi(C1) & Biaya(C2) & Lokasi(C3) & Jumlah Pelajar(C4) \\
\hline NCF & NCF & NSF & NSF \\
\hline 0.4 & 0.3 & 0.2 & 0.1 \\
\hline
\end{tabular}

Keterangan :

NCF : Nilai Rata-Rata Core Factor

NSF : Nilai Rata-Rata Secondary Factor

Berikut adalah nilai gap untuk perubahan nilai bobot FSAW menggunakan Profile Matching :

Tabel 3. Nilai Pembobotan

\begin{tabular}{|c|c|c|l|}
\hline No & Selisih & Bobot Nilai & \multicolumn{1}{c|}{ Keterangan } \\
\hline 1 & 0 & 5 & Tidak ada selisih (kompetensi sesuai dengan yang dibutuhkan) \\
\hline 2 & 1 & 4.5 & Kompetensi individu kelebihan 1 tingkat/level \\
\hline 3 & -1 & 4 & Kompetensi individu kekurangan 1 tingkat/level \\
\hline 4 & 2 & 3.5 & Kompetensi individu kelebihan 2 tingkat/level \\
\hline 5 & -2 & 3 & Kompetensi individu kekurangan 2 tingkat/level \\
\hline 6 & 3 & 2.5 & Kompetensi individu kelebihan 3 tingkat/level \\
\hline 7 & -3 & 2 & Kompetensi individu kekurangan 3 tingkat/level \\
\hline 8 & 4 & 1.5 & Kompetensi individu kelebihan 4 tingkat/level \\
\hline 9 & -4 & 1 & Kompetensi individu kekurangan 4 tingkat/level \\
\hline
\end{tabular}

3. Penilaian Pada Setiap Kriteria

Untuk Akreditasi $(\mathrm{C} 1)$

Tabel 4 Tabel nilai normalisasi $\mathrm{C} 1$

\begin{tabular}{|c|c|c|}
\hline Akreditasi & Bobot & Nilai Crisp \\
\hline A & $40 \%$ & 0.4 \\
\hline B & $30 \%$ & 0.3 \\
\hline C & $20 \%$ & 0.2 \\
\hline D & $10 \%$ & 0.1 \\
\hline
\end{tabular}

Untuk Biaya(C2)

Tabel 5. Tabel nilai normalisasi $\mathrm{C} 2$

\begin{tabular}{|c|c|c|}
\hline Biaya & Bobot & Nilai Crisp \\
\hline$>200000$ & $40 \%$ & 0.4 \\
\hline $200000-300000$ & $30 \%$ & 0.3 \\
\hline $100000-200000$ & $20 \%$ & 0.2 \\
\hline$<100000$ & $10 \%$ & 0.1 \\
\hline
\end{tabular}

Untuk Lokasi(C3)

Tabel 6. Tabel nilai normalisasi C3

\begin{tabular}{|c|c|c|}
\hline Lokasi & Bobot & Nilai Crisp \\
\hline$<1 \mathrm{Km}$ & $40 \%$ & 0.4 \\
\hline $1 \mathrm{Km}-1.5 \mathrm{Km}$ & $30 \%$ & 0.3 \\
\hline $1.5 \mathrm{Km}-2 \mathrm{Km}$ & $20 \%$ & 0.2 \\
\hline$>2 \mathrm{Km}$ & $10 \%$ & 0.1 \\
\hline
\end{tabular}

Untuk Jumlah Pelajar(C4) 
Tabel 7 Tabel nilai normalisasi C4

\begin{tabular}{|c|c|c|}
\hline Jumlah Pelajar & Bobot & Nilai Crisp \\
\hline$>35$ Perkelas & $40 \%$ & 0.4 \\
\hline 30-35 Perkelas & $30 \%$ & 0.3 \\
\hline 25-30 Perkelas & $20 \%$ & 0.2 \\
\hline$<25$ Perkelas & $10 \%$ & 0.1 \\
\hline
\end{tabular}

4. Input Nilai Pada Setiap Kriteria

Berikut adalah tabel input nilai pada setiap kriteria:

Tabel 8. Tabel Input Nilai Kriteria

\begin{tabular}{|c|c|c|c|c|}
\hline \multirow{2}{*}{ Madrasah } & \multicolumn{4}{|c|}{ Nilai } \\
\cline { 2 - 5 } & $\mathrm{C} 1$ & $\mathrm{C} 2$ & $\mathrm{C} 3$ & $\mathrm{C} 4$ \\
\hline Madrasah 1 & 0.2 & 0.2 & 0.2 & 0.2 \\
\hline Madrasah 2 & 0.2 & 0.1 & 0.2 & 0.2 \\
\hline Madrasah 3 & 0.2 & 0.1 & 0.1 & 0.1 \\
\hline GAP & 0.2 & 0.2 & 0.2 & 0.2 \\
\hline Madrasah 1 & -0.3 & -0.3 & -0.3 & -0.3 \\
\hline Madrasah 2 & -0.3 & -0.4 & -0.3 & -0.3 \\
\hline Madrasah 3 & -0.3 & -0.4 & -0.4 & -0.4 \\
\hline MAX & -0.3 & -0.3 & -0.3 & -0.3 \\
\hline
\end{tabular}

5. Rumus Metode FSAW

Kemudian nilai dinormalisasikan, jika benefit dengan rumus :

$\mathrm{rij}=\frac{\mathrm{Xij}}{\mathrm{Xij}}$

Max Xij

Jika cost dengan rumus :

$\mathrm{rij}=\underset{\mathrm{Xij}}{\operatorname{Max} \mathrm{Xij}}$

Maka didapat 1

$\mathrm{R} 11=\operatorname{Max}(-0.3 ;-0.3 ;-0.3) /-0.3=-0.3 /-0.3=1$

$\mathrm{R} 21=\operatorname{Max}(-0.3 ;-0.4 ;-0.4) /-0.3=-0.3 /-0.3=1$

$\mathrm{R} 31=-0.3 / \operatorname{Max}(-0.3 ;-0.3 ;-0.4)=-0.3 /-0.3=1$

$\mathrm{R} 41=-0.3 / \operatorname{Max}(-0.3 ;-0.3 ;-0.4)=-0.3 /-0.3=1$

$\mathrm{R} 12=\operatorname{Max}(-0.3 ;-0.3 ;-0.3) /-0.3=-0.3 /-0.3=1$

$\mathrm{R} 22=\operatorname{Max}(-0.3 ;-0.4 ;-0.4) /-0.4=-0.3 /-0.4=0.75$

$\mathrm{R} 32=-0.3 / \operatorname{Max}(-0.3 ;-0.3 ;-0.4)=-0.3 /-0.3=1$

$\mathrm{R} 42=-0.3 / \operatorname{Max}(-0.3 ;-0.3 ;-0.4)=-0.3 /-0.3=1$

$\mathrm{R} 13=\operatorname{Max}(-0.3 ;-0.3 ;-0.3) /-0.3=-0.3 /-0.3=1$

$\mathrm{R} 23=\operatorname{Max}(-0.3 ;-0.4 ;-0.4) /-0.4=-0.3 /-0.4=0.75$

$\mathrm{R} 33=-0.4 / \operatorname{Max}(-0.3 ;-0.3 ;-0.4)=-0.4 /-0.3=1.3$

$\mathrm{R} 43=-0.4 / \operatorname{Max}(-0.3 ;-0.3 ;-0.4)=-0.4 /-0.3=1.3$

Setelah semua perhitungan selesai maka didapatlah nilai yang telah dinormalisasi

Tabel 9. Tabel Proses Normalisasi

\begin{tabular}{|c|c|c|c|c|}
\hline Madrasah & \multicolumn{4}{|c|}{ Nilai } \\
\hline & C1 & C2 & C3 & C4 \\
\hline & NCF & NCF & NSF & NSF \\
\hline Madrasah 1 & 1 & 1 & 1 & 1 \\
\hline
\end{tabular}




\begin{tabular}{|c|c|c|c|c|}
\hline Madrasah 2 & 1 & 1.3 & 1 & 1 \\
\hline Madrasah 3 & 1 & 1.3 & 0,75 & 0,75 \\
\hline
\end{tabular}

6. Perhitungan NCF Dan NSF

Yang menjadi core factor yaitu $\mathrm{C} 1$ dan $\mathrm{C} 2$, sedangkan yang menjadi secondary factor yaitu $\mathrm{C} 3$ dan C4. Selanjutnya dilakukan perhitungan core factor dan secondary factor sebagai berikut :

Tabel 10. Perhitungan NCF Dan NSF

\begin{tabular}{|c|c|c|c|c|}
\hline Madrasah 1 & 1 & 1 & 1 & 1 \\
\hline Madrasah 2 & 1 & 0.75 & 1 & 1 \\
\hline Madrasah 3 & 1 & 0.75 & 1.3 & 1.3 \\
\hline Bobot & 0.4 & 0.3 & 0.2 & 0.1 \\
\hline Madrasah 1 & 0.4 & 0.3 & 0.2 & 0.1 \\
\hline Madrasah 2 & 0.4 & 0.225 & 0.2 & 0.1 \\
\hline Madrasah 3 & 0.4 & 0.225 & 0.26 & 0.13 \\
\hline
\end{tabular}

a. Madrasah 1

$\mathrm{NCF}=(\mathrm{C} 1+\mathrm{C} 2) / 2=(0.4+0.3) / 2=0,35$
$\mathrm{NSF}=(\mathrm{C} 1+\mathrm{C} 2) / 2=(0.2+0.1) / 2=0.15$

b. Madrasah 2

$\mathrm{NCF}=(\mathrm{C} 1+\mathrm{C} 2) / 2=(0.4+0.225) / 2=0.3125$

$\mathrm{NSF}=(\mathrm{C} 1+\mathrm{C} 2) / 2=(0.2+0.1) / 2=0.15$

c. Madrasah 3

$\mathrm{NCF}=(\mathrm{C} 1+\mathrm{C} 2) / 2=(0.4+0.225) / 2=0.3125$

$\mathrm{NSF}=(\mathrm{C} 1+\mathrm{C} 2) / 2=(0.26+0.13) / 2=0.195$

Bila input persentase core factor adalah $60 \%$ dan secondary factor adalah $40 \%$, maka perhitungan nilai total adalah sebagai berikut :

a. Madrasah 1

$\mathrm{N}=(60 \% * \mathrm{NCF})+(40 \% * \mathrm{NSF})$

$\mathrm{N}=(60 \% * 0.35)+(40 \% * 0.15)$

$\mathrm{N}=0.21+0.06=0.27$

b. Madrasah 2

$\mathrm{N}=(60 \% * \mathrm{NCF})+(40 \% * \mathrm{NSF})$

$\mathrm{N}=(60 \% * 0.3125)+(40 \% * 0,15)$

$\mathrm{N}=0.1875+0.06=0.2475$

c. Madrasah 3

$\mathrm{N}=(60 \% * \mathrm{NCF})+(40 \% * \mathrm{NSF})$

$\mathrm{N}=(60 \% * 0.3125)+(40 \% * 0.195)$

$\mathrm{N}=0.1875+0.078=0.2655$

7. Hasil Akhir

Setelah hasil didapat seperti pada tabel maka tahap berikutnya adalah sebagai berikut :

Tabel 11. Tabel Proses Normalisasi A1

\begin{tabular}{|c|c|c|}
\hline Madrasah & Nilai & Keputusan \\
\hline Madrasah 1 & 0.27 & Terpilih \\
\hline Madrasah 2 & 0.2475 & Tidak \\
\hline Madrasah 3 & 0.2655 & Tidak \\
\hline
\end{tabular}

Berdasarkan hasil perhitungan diatas maka madrasah 1 terpilih sebagai madrasah terbaik.

\subsection{Tampilan Hasil}


1. Tampilan Hasil Form Madrasah

Tampilan hasil form madrasah dari aplikasi yang telah dibuat dapat dilihat pada gambar 2 .

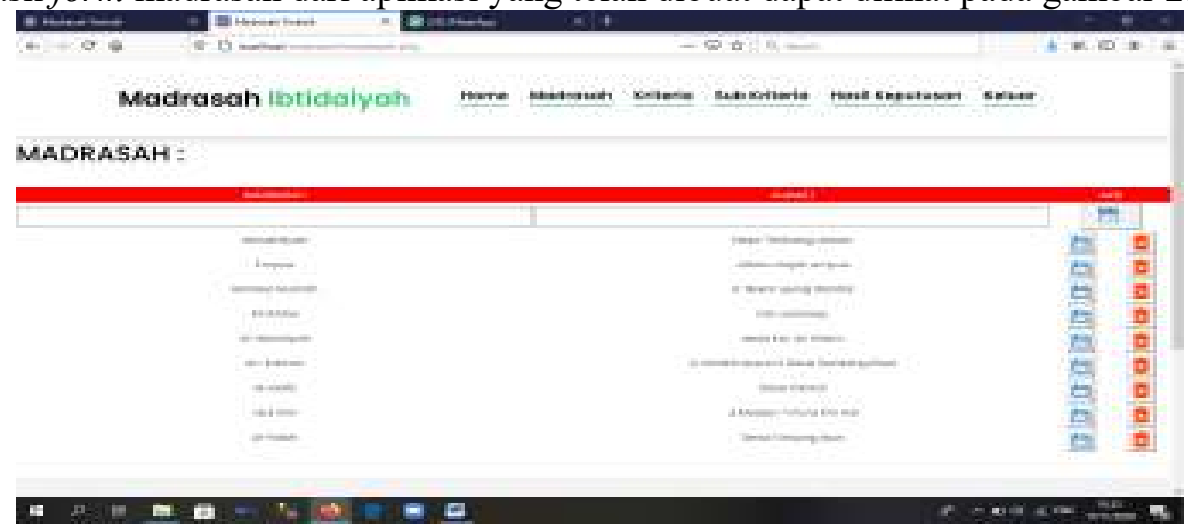

Gambar 2. Tampilan Hasil Form Madrasah

2. Tampilan Hasil Form Kriteria

Tampilan hasil form kriteria dari aplikasi yang telah dibuat dapat dilihat pada gambar 3

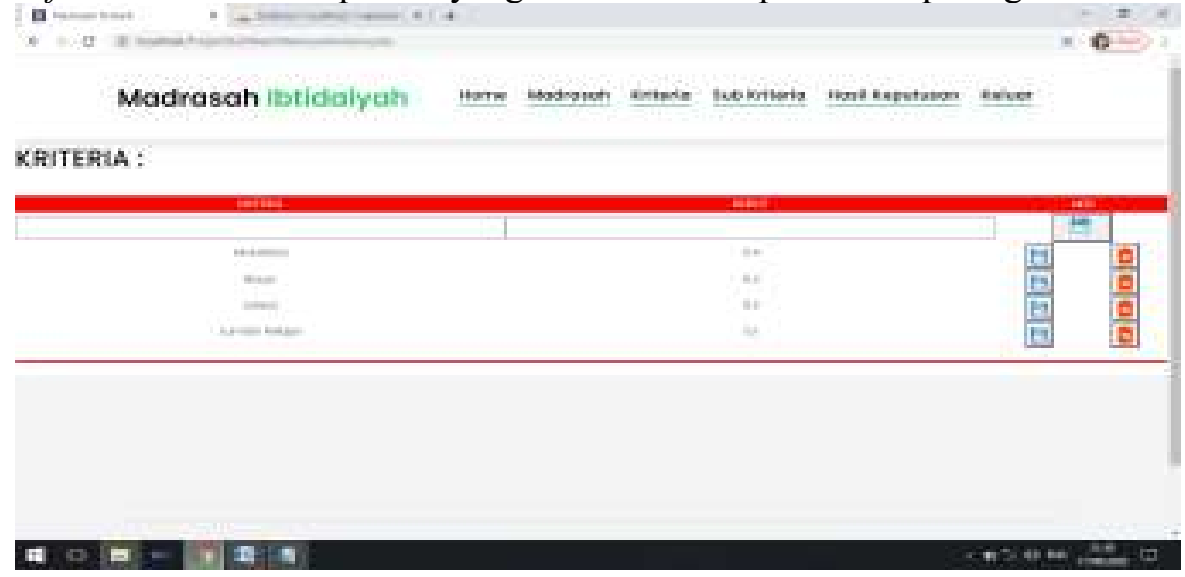

Gambar 3. Tampilan Hasil Form Kriteria

3. Tampilan Hasil Form Sub Kriteria

Tampilan hasil Form Sub Kriteria dari aplikasi yang telah dibuat dapat dilihat pada gambar 4.

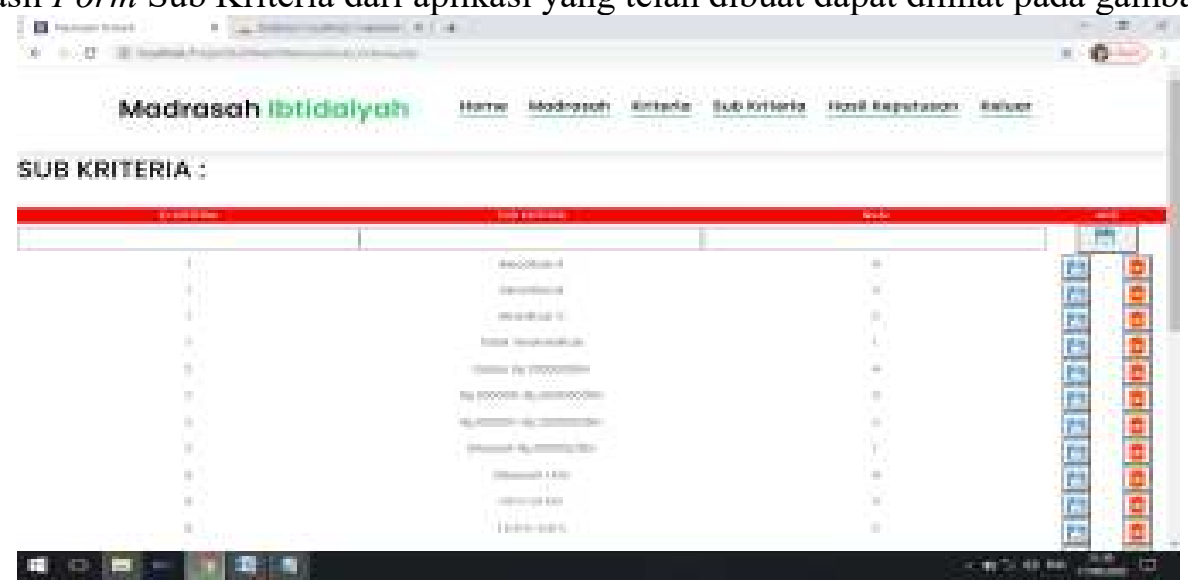

Gambar 4. Tampilan Hasil Form Sub Kriteria

4. Tampilan Hasil Form Hasil Keputusan

Tampilan Hasil Form Hasil Keputusan dari aplikasi yang telah dibuat dapat dilihat pada gambar 5. 


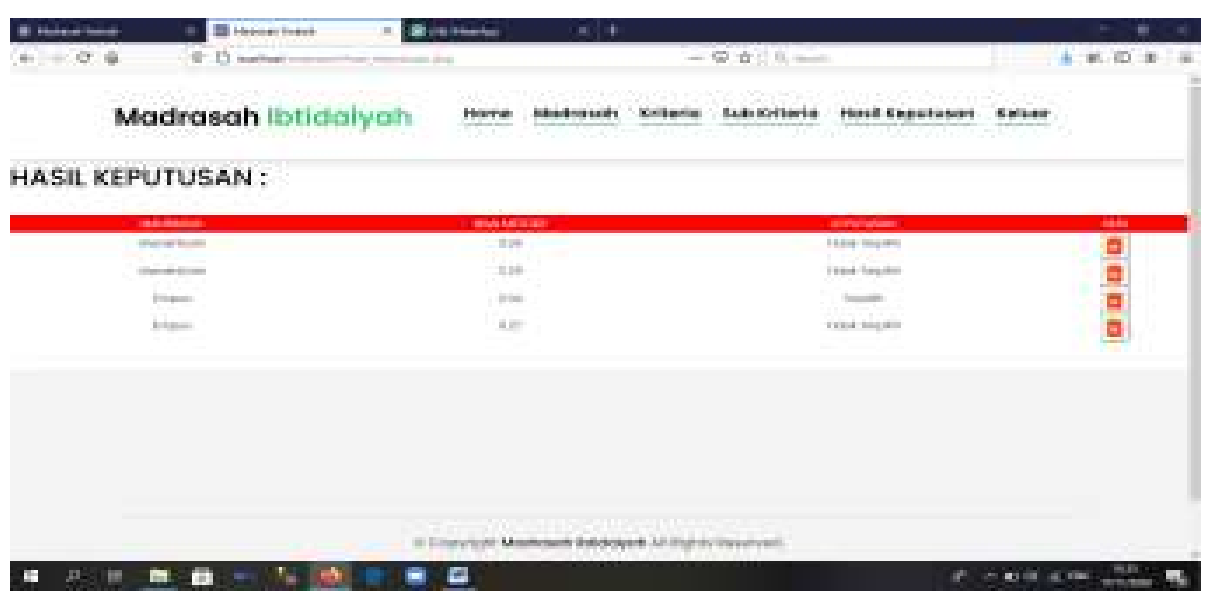

Gambar 5. Tampilan Hasil Form Hasil Keputusan

Uji coba terhadap sistem bertujuan untuk memastikan bahwa sistem sudah berada pada kondisi siap pakai. Instrumen yang digunakan untuk melakukan pengujian ini yaitu dengan menggunakan Blackbox Testing :

Tabel. 12. Blackbox Testing Form Login

\begin{tabular}{|c|l|l|c|}
\hline No. & \multicolumn{1}{|c|}{ Form Login } & \multicolumn{1}{|c|}{ Harapan } & Hasil \\
\hline 1. & Isi Sandi Dan Klik Tombol SUBMIT & Sistem menampilkan form menu & Sesuai \\
\hline 2. & Klik Keputusan & Sistem menampilkan form keputusan & Sesuai \\
\hline
\end{tabular}

Tabel. 13. Blackbox Testing Form Menu

\begin{tabular}{|c|l|l|c|}
\hline No. & \multicolumn{1}{|c|}{ Form Menu } & \multicolumn{1}{c|}{ Harapan } & Hasil \\
\hline 1. & Klik Tombol Home & Sistem menampilkan menu utama & Sesuai \\
\hline 2. & Klik Tombol Madrasah & Sistem menampilkan form madrasah & Sesuai \\
\hline 3. & Klik Tombol Kriteria & Sistem menampilkan form Kriteria & Sesuai \\
\hline 4. & Klik Tombol Sub Kriteria & Sistem menampilkan form Sub Kriteria & Sesuai \\
\hline 5. & Klik Tombol Hasil Keputusan & Sistem menampilkan form Hasil Keputusan & Sesuai \\
\hline 6. & Klik Tombol Keluar & Sistem menampilkan form Login & Sesuai \\
\hline
\end{tabular}

Tabel. 14. Blackbox Testing Form Madrasah

\begin{tabular}{|c|l|l|c|}
\hline No. & \multicolumn{1}{|c|}{ Form Madrasah } & \multicolumn{1}{|c|}{ Harapan } & Hasil \\
\hline 1. & Klik Tombol Simpan & $\begin{array}{l}\text { Sistem menyimpan seluruh isi text ke dalam } \\
\text { database }\end{array}$ & Sesuai \\
\hline 2. & Klik Tombol Ubah & Sistem menampilkan form pengubah data & Sesuai \\
\hline 3. & Klik Tombol Hapus & Sistem menghapus isi database sesuai dengan id & Sesuai \\
\hline
\end{tabular}

Tabel. 15. Blackbox Testing Form Kriteria

\begin{tabular}{|c|l|l|c|}
\hline No. & \multicolumn{1}{|c|}{ Form Kriteria } & \multicolumn{1}{|c|}{ Harapan } & Hasil \\
\hline 1. & Klik Tombol Simpan & $\begin{array}{l}\text { Sistem menyimpan seluruh isi text ke dalam } \\
\text { database }\end{array}$ & Sesuai \\
\hline 2. & Klik Tombol Ubah & Sistem menampilkan form pengubah data & Sesuai \\
\hline 3. & Klik Tombol Hapus & Sistem menghapus isi database sesuai dengan id & Sesuai \\
\hline
\end{tabular}

Tabel. 16. Blackbox Testing Form Sub Kriteria

\begin{tabular}{|c|l|l|c|}
\hline No. & \multicolumn{1}{|c|}{ Form Sub Kriteria } & \multicolumn{1}{|c|}{ Harapan } & Hasil \\
\hline 1. & Klik Tombol Simpan & Sistem menyimpan seluruh isi text ke dalam database & Sesuai \\
\hline 2. & Klik Tombol Ubah & Sistem menampilkan form pengubah data & Sesuai \\
\hline 3. & Klik Tombol Hapus & Sistem menghapus isi database sesuai dengan id & Sesuai \\
\hline
\end{tabular}


Tabel. 17. Blackbox Testing Form Keputusan

\begin{tabular}{|c|c|c|c|}
\hline No. & Form Keputusan & Harapan & Hasil \\
\hline 1. & Isi data kemudian klik tombol keputusan & Sistem menampilkan hasil keputusan & Sesuai \\
\hline
\end{tabular}

Tabel. 18. Blackbox Testing Form Hasil Keputusan

\begin{tabular}{|c|l|l|c|}
\hline No. & \multicolumn{1}{|c|}{ Form Hasil Keputusan } & \multicolumn{1}{c|}{ Harapan } & Hasil \\
\hline 1. & Klik Tombol Hapus & $\begin{array}{l}\text { Sistem menghapus isi database sesuai dengan id } \\
\text { keputusan }\end{array}$ & Sesuai \\
\hline
\end{tabular}

\section{KESIMPULAN}

Berdasarkan pembahasan sebelumnya yang telah dilakukan maka dapat diambil beberapa kesimpulan sebagai berikut :

1. Dengan menggunakan sistem pendukung keputusan maka para orang tua dapat memilih Madrasah Ibtidaiyah terbaik untuk anak-anaknya.

2. Dengan menggabungkan rumus dan langkah dari metode profile matching dan fuzzy SAW maka kedua metode dapat dikombinasikan untuk keputusan pemilihan Madrasah Ibtidaiyah terbaik.

3. Dengan menggunakan pemrograman web maka dapat menghasilkan aplikasi Sistem Pendukung Keputusan Pemilihan Madrasah Ibtidaiyah Terbaik Dengan Kombinasi Metode Profile Matching Dan Fuzzy SAW

\section{SARAN}

Berdasarkan kekurangan sistem dan hasil penelitian maka peneliti memberikan beberapa saran untuk pengembangan selanjutnya yaitu :

1. Sebaiknya aplikasi dapat memberikan keputusan selain pemilihan madrasah ibtidaiyah.

2. Sebaiknya aplikasi memiliki petunjuk penggunaan.

3. Sebaiknya aplikasi dapat membandingkan dua metode sistem pendukung keputusan.

\section{UCAPAN TERIMA KASIH}

Penulis mengucapkan terima kasih kepada Universitas Potensi Utama yang telah banyak memberikan masukkan dan saran dalam penyelesaian Penelitian ini.

\section{DAFTAR PUSTAKA}

[1] Angeline, M. (2018). Sistem Pendukung Keputusan Pemilihan Karyawan Terbaik Menggunakan Metode Profile Matching. Jurnal Ilmiah Smart, 2(2), 45-51.

[2] Handayani, R. I. (2017). Sistem pendukung keputusan pemilihan karyawan berprestasi dengan metode profile matching pada PT. Sarana Inti Persada (SIP). Jurnal Pilar Nusa Mandiri, 13(1), $28-34$.

[3] Hastuti, T. P., \& Wismarini, T. D. (2019). Implementasi Metode Fuzzy Saw Untuk Pemilihan Laptop Pada Sistem Pendukung Keputusan Berbasis Web.

[4] Muslihudin, M., Kurniawan, D., \& Widyaningrum, I. (2017). Implementasi Model Fuzzy SAW Dalam Penilaian Kinerja Penyuluh Agama (Studi Kasus: Kementerian Agama Kabupaten Pringsewu). Jurnal TAM (Technology Acceptance Model), 8(1), 39-44.

[5] Negoro, S. Y., \& Abadi, S. (2017). Aplikasi Sistem Pendukung Keputusan Menggunakan Metode Fuzzy Sample Additive Weighting (SAW) Dalam Menentukan Kelaikan Installasi Listrik Yang Terpasang Di Rumah Pelanggan. Jurnal TAM (Technology Acceptance Model), 5, 73-79. 